\title{
Efisiensi Reproduksi Induk Sapi Bali yang dikawinkan dengan Bangsa Sapi Brangus secara Inseminasi Buatan di Kecamatan Insana Barat Kabupaten Timor Tengah Utara
}

\author{
Alexander Manhitu ${ }^{\mathrm{a}}$, Paulus K. Tahuk ${ }^{\mathrm{b}}$ dan Theresia I. Purwantiningsih ${ }^{\mathrm{c}}$ \\ ${ }^{a}$ Fakultas Pertanian, Universitas Timor, Kefamenanu, TTU - NTT, 85613, Indonesia,email: manhitua@gmail.com \\ ${ }^{b}$ Fakultas Pertanian, Universitas Timor, Kefamenanu, TTU - NTT, 85613, Indonesia,email: paulklau@yahoo.co.id \\ ${ }^{c}$ Fakultas Pertanian, Universitas Timor, Kefamenanu, TTU - NTT, 85613, Indonesia,email: theresiaicha@gmail.com
}

\section{Article Info}

\section{Article history:}

Received 29 Januari 2020

Received in revised form 23 Maret 2020

https://doi.org/10.32938/ja.v5i2.990

Keywords:

Efisiensi reproduksi

IB

Sapi Bali

Semen sapi brangus Accepted 14 April 2020

\begin{abstract}
Abstrak
Penelitian ini bertujuan untuk mengetahui efisiensi reproduksi induk sapi Bali yang dikawinkan dengan bangsa sapi brangus secar Inseminasi Buatan (IB) di Kecamatan Insana Barat Kabupaten Timor Tengah Utara. Penelitian ini dilaksanakan selama dua bulan di wilayah Kecamatan Insana Barat, Kabupaten Timor Tengah Utara pada bulan Juli 2019 sampai dengan september 2019. Metode yang digunakan dalam penelitian ini adalah metode sensus yang dilakukan terhadap Induk sapi Bali betina yang pernah di IB minimal satu kali bunting dan atau telah melahirkan, menggunakan semen pejantan Brangus (sampel). Data primer diperoleh dari hasil wawancara dan pengamatan langsung (berpedoman pada kuesioner yang telah disiapkan) dengan sejumlah peternak yang memiliki induk sapi Bali dengan jumlah pemilikan minimal 2 ekor. Sedangkan data sekunder diperoleh dari berbagai instansi terkait dengan penelitian ini seperti Dinas Peternakan, monografi Kecamatan, dan kantor Badan Pusat Statistik. Disimpulkan bahwa rata-rata induk sapi Bali yang dikawinkan secara IB dengan semen pejantan sapi Bragus memberikan efisiensi reproduksi yang baik dan di atas normal dengan nilai masing-masing variabel adalah: CR: $68,70 \pm 26,83 \%$; S/C: $1,73 \pm$ 0,79; Lama kebuntingan: 272,23 $\pm 3,96$ hari, CI: 384,62 \pm 48,41 hari. Efisiensi reproduksi induk sapi Bali yang dikawinkan secara IB dengan semen pejantan sapi Brangus memiliki keeratan hubungan dengan Service Per Conception, Conception Rate dan Calving interval.
\end{abstract}

\section{Pendahuluan}

Sapi merupakan jenis ternak yang digemari dan banyak diusahakan oleh peternak di Indonesia, khususnya sapi potong yang merupakan ternak penghasi daging yang memiliki kandungan protein serta nilai ekonomis tinggi. Usaha sapi potong di Indonesia umumnya masih bersifat tradisional (Kurniawan, 2012). Kebutuhan daging dari tahun ke tahun terus mengalami peningkatan seiring dengan bertambahnya jumlah penduduk, peningkatan pendapatan dan kesejahteraan masyarakat serta semakin tingginya tingkat kesadaran masyarakat akan pentingnya protein hewani. Di sisi lain penyediaan daging masih tergolong rendah apabila dibandingkan dengan permintaan. Data konsumsi daging terus meningkat dimana pada tahun 2016 konsumsi daging sapi sebesar $0,417 \mathrm{~kg} / \mathrm{kapita} / \mathrm{tahun}$, dan pada tahun 2017 sebesar 0,469 $\mathrm{kg} / \mathrm{kapita} /$ tahun mengalami peningkatan sebesar $12,50 \%$ (Dirjen Peternakan dan Keswan, 2018). Di mana populasi sapi potong tahun 2016 berjumlah 123.406 ekor, dan pada tahun 2017 berjumlah 122.771 ekor, terjadi penurunan populasi ternak sebesar 635 ekor (BPS Prov. NTT, 2019). Kondisi ini akan menyebabkan penurunan populasi ternak sapi potong berkelanjutan yang berada di Kabupaten Timor Tengah Utara. Untuk mengurangi kesenjangan in diperlukan berbagai upaya yang mampu meningkatkan produktivitas, terlebih pada peternakan sapi potong rakyat (Nuryadi dan Wahjuningsih, 2011).

Akibat peningkatan konsumsi daging sapi terus meningkat per tahun, maka upaya yang dilakukan pemerintah untuk meningkatkan populasi dan mutu genetik ternak sapi potong yakni dengan menggunakan teknologi Insemins Buatan (IB) (Feradis, 2010). Inseminasi Buatan (IB) adalah salah satu teknologi reproduksi yang telah dan sedang diprogramkan oleh pemerintah dalam rangka pembangunan peternakan sebagai upaya peningkatan produktivitas ternak demi meningkatkan pendapatan dan kesejahteraan petani peternak. Oleh karena itu produktivitas sapi potong perlu ditingkatkan salah satunya adalah dengan menyilangkan sapi bali betina dengan pejantan unggul misalnya brangus melalui progam IB.

Wilayah Insana Barat merupakan salah satu lokasi perkembangbiakan sapi potong di Kabupaten Timor Tengah Utara yang menggunakan bioteknologi reproduksi ternak yaitu IB. Penerapan teknologi IB sebagai upaya peningkatan populasi dan produktivitas tenak sapi potong dengan mengawinkan induk sapi bali dengan bangsa pejantan impor (Exotic boced) yakni salah satunya bangsa sapi brangus. Alasan mengapa memilih sapi brangus karena sapi brangus memiliki keunggulan yaitu pertumbuhan yang cepat, performa reproduksi yang baik, persentase karkas tinggi, adaptasi dengan lingkungan sangat baik dan kemampuan memanfaatkan pakan yang berkualitas rendah. Keberhasilan teknologi IB sebagai salah satu usaha perkembangbiakan sangat erat kaitannya dengan efisiensi reproduksi, dimana efisiensi reproduksi induk betina sebagai akseptor seperti Service perconception (S/C), Conception rate (CR) dan lama bunting juga dipengaruhi oleh bangsa sapi pejantan (Sariubang et al., 2001). Meskipun pejantan brangus sebagai ternak unggul telah digunakan untuk mengawini induk sapi bali, namun sejauh ini belum diketahui efisiensi reproduksi induk sapi bali yang di kawinkan dengan semen pejantan sapi brangus tersebut di Kecamatan Insana Barat.

\section{Metode}

\subsection{Lokasi dan Waktu Penelitian}

Penelitian ini telah dilaksanakan selama sebulan di wilayah Kecamatan Insana Barat, Kabupaten Timor Tengah Utara pada bulan Juli 2019 sampai dengan September 2019

\subsection{Materi Penelitian}

Materi yang digunakan dalam penelitian ini adalah induk sapi bali milik petani peternak yang telah atau sudah pernah di IB menggunakan semen pejantan bangsa brangus di wilayah Kecamatan Insana Barat, Kabupaten Timor Tengah Utara, sehingga total dari data yang diperoleh saat sensus di jadikan sebagai sampel.

\subsection{Populasi dan Sampel}

Populasi dalam penelitian ini adalah seluruh peternak sapi Bali yang menggunakan teknologi IB yang ada di wilayah kecamatan Insana Barat Kabupaten Timor Tengah Utara. Penentuan sampel ditentukan secara sengaja (purposive sampling) dengan pertimbangan tertentu (Sugiyono, 2010), yaitu wilayah yang memiliki populasi ternak sapi potong terbanyak yang telah diikut sertakan dalam program IB dengan menggunakan semen pejantan sapi Brangus. Pemilihan responden peternak sapi bali menggunakan metode purposive sampling, karena tidak semua sampel anggota dalam populasi menggunakan teknologi IB dengan semen pejantan sapi Brangus.

\subsection{Metode Penelitian}

Metode yang digunakan dalam penelitian ini adalah metode sensus yang dilakukan terhadap induk sapi bali betina yang pernah di IB minimal satu kali bunting dan atau telah melahirkan, menggunakan semen pejantan brangus (sampel). Data primer diperoleh dari hasil wawancara dan pengamatan langsung (berpedoman pada kuesioner yang telah disiapkan) dengan sejumlah peternak yang memiliki induk sapi bali dengan jumlah pemilikan minimal 2 ekor. Sedangkan data sekunder diperoleh dari berbagai instansi terkait dengan penelitian ini seperti Dinas Peternakan, monografi Kecamatan, dan kantor Badan Pusat Statistik.

\subsection{Variabel Penelitian}

Variabel yang diamati dalam penelitian ini adalah: Service per Conception (S/C), Conception Rate (CR), Lama Bunting, Calving Interval (CI)

\subsection{Analisis Data}

Data yang diperoleh dari lapangan dianalisis menggunakan dua alat analisis yakni : (a) analisis deskriptif, dan (b) analisis regresi. Untuk analisis deskriptif mengacu pada model analisis teknis yakni :

\section{Service per Conception (S/C)}

Perhitungan nilai S/C menurut (Hafez, 1993) yaitu dengan menggunakan rumus sebagai berikut:

Bilamana:

$\mathrm{S} / \mathrm{C} 1=$ induk betina yang sekali dikawinkan langsung bunting.

$\mathrm{S} / \mathrm{C} 2=$ induk betina yang di kawinkan lebih dari 1 kali baru bunting.

$\mathrm{S} / \mathrm{C} 3=$ induk betina yang dikawinkan lebih dari 2 kali baru bunting.

\section{Conception rate $(\mathrm{CR})$}

Perhitungan nilai CR menurut Jaenudeen dan Hafez (1993) yaitu dengan menggunakan rumus sebagai berikut: CR $(\%)=\frac{\text { Jumlah betina bunting yang kawin pertama }}{\text { Jumlah Seluruh Betina Yang Kawin }} \times 100 \%$

\section{Calving interval}

Calving Interval adalah jangka waktu antara satu kelahiran dengan kelahiran berikutnya. Nilai normal Calving interval adalah 365-400 hari (Hariadi et al., 2011)
$\mathrm{S} / \mathrm{C}=\frac{\text { Jumlah Perkawinan }}{\text { Jumlah Betina Bunting }}$ 
Untuk mengetahui hubungan antara jumlah akseptor IB dengan tingkat efisiensi reproduksi menggunakan persamaan regresi. Untuk memudahkan analisis data diolah dalam program SPSS (statistic packet for social science) model umum regresi adalah sebagai berikut $: \mathrm{Y}=\mathrm{a}+\mathrm{b}_{1} \mathrm{X}_{1}+\mathrm{b}_{2} \mathrm{X}_{2}+\mathrm{b}_{3} \mathrm{X}_{3}$ (Sarwono, 2006).

\section{Hasil dan Pembahasan}

\subsection{Gambaran Umum Lokasi Penelitian}

Kecamatan Insana Barat merupakan salah satu kecamatan hasi pemekaran dari kecamatan Insana dan resmi menjadi sebuah kecamatan pada Tahun 2008, yang berada diwilayah Kabupaten Timor Tengah Utara, Propinsi Nusa Tenggara Timur, dengan luas wilayah (daratan) adalah $117,70 \mathrm{~km}^{2}$ atau hanya sebesar 3,82\% dari luas wilayah Kabupaten Timor Tengah Utara, dan bukan merupakan daerah pantai dengan kisaran ketinggian lebih dari 500mdpl. Secara astronomis Kecamatan Insana Barat terletak antara $124^{\circ} 29^{\prime} 20^{\prime \prime}$ E - $124^{\circ}$ $39^{\prime} 40^{\prime \prime} \mathrm{E}$ dan $9^{0} \quad 32^{\prime} 0^{\prime \prime} \mathrm{S}-9^{0} 23^{\prime} 30^{\prime}$ 'S. Berdasarkan posisi geografisnya, Kecamatan Insana Barat memiliki batas-batas sebagai berikut: Sebelah utara berbatasan dengan Kecamatan Insana Tengah; Sebelah selatan berbatasan dengan Kecamatan Bikomi Selatan; Sebelah timur berbatasan dengan Kecamatan Insana; dan Sebelah barat berbatasan dengan Kecamatan Kota Kefamenanu (BPS. Kab. TTU, 2018).

Ada 12 desa dalam wilayah Kecamatan Insana Barat yang antara lain Subun, Lapeom, Usapinonot, Unini, Letneo, Banae, Atmen, Letneo Selatan, Nifunenas, Subun Tualele, Subun Bestobe, dan Oabikase. Adapun terdapat 6 desa yang dipilih sebagai lokasi penelitian karena memiliki populasi ternak sapi bali terbanyak yang diikutsertakan dalam program IB, yakni desa Subun sebanyak (7 ekor sapi betina), Lapeom (10 ekor sapi betina), Usapinonot Unini (12 ekor sapi betina), Letneo ( 5 ekor sapi betina), Banaen (4 ekor sapi betina), dan Atmen (4 ekor sapi betina).

Seperti halnya diwilayah lain di kabupaten Timor Tengah Utara, Kecamatan Insana Barat juga hanya dikenal dua musim yaitu kemarau dan hujan. Secara umum, musim kemarau terjadi pada bulan Juni sampai Oktober, sedangkan musim hujan pada bulan Desember sampai Maret dan memiliki populasi ternak sapi Bali sebanayak 5.475 ekor (BPS. Kab. TTU, 2018).

\subsection{Karakteristik Responden}

Karakteristik responden dilakukan untuk mengetahui identitas peternak yang terlibat dalam penelitian ini. Adapun karakteristik responden yang diperoleh meliputi umur, tingkat pendidikan, pekerjaan utama, pengalaman beternak, jumlah kepemilikan ternak, status kepemilikan dan sistem pemeliharaan ternak. Ketujuh komponen karakteristik ini diduga mempunyai hubungan yang erat dengan tingkat keberhasilan peternak dalam mengelolah usaha ternak terutama dalam hal efisiensi reproduksi ternaknya. Adapun deskripsi karakteristik responden seperti terlihat pada Tabel 1.

Data pada Tabel 1 terlihat bahwa sebagian besar responden berada pada usia yang relatif produktif. Hasil penelitian menunjukkan rata-rata umur peternak sapi potong terbanyak adalah berumur antara 44 sampai 55 tahun (produktif) yakni 14 orang (43,75\%). Menyusul kisaran umur lebih dari 55 tahun (kurang produktif) sebanyak 11 orang $(34,38 \%)$ dan sisanya berumur kurang dari 45 tahun (sangat produktif) sebanyak 7 orang $(21,88 \%)$. Kondisi tersebut memberikan gambaran bahwa peternak di lokasi penelitian secara umum berada dalam kategori umur produktif.

Untuk tingkat pendidikan, dari Tabel 1 menunjukkan bahwa rata-rata peternak yang berpendidikan tidak tamat SD adalah sebanyak 3 orang responden dari 32 orang responden dengan nilai persentasenya adalah 9 , $38 \%$.Pendidikan tamat SD sebanyak 12 orang $(37,50 \%)$; Pendidikan tamat SLTP/sederajat sebanyak 6 orang $(18,75 \%)$; Pendidikan tamat SLTA/sederajat sebanyak 9 orang $(28,13 \%)$ dan Pendidikan S1 atau S2 sebanyak 2 orang $(6,25 \%)$. Hal ini mengindikasikan bahwa umumnya responden lebih memilih jadi peternak dibanding bersekolah dengan alasan yang beragam sehingga peternak yang berada di Kecamatan Insana Barat hanya mengenyam pendidikan terakhir terbanyak adalah tamat Sekolah Dasar (SD) atau sederajatnya atau bahkan tidak bersekolah. Menurut Waris et al., (2015), pendidikan tidak mempengaruhi keberlangsungan usaha ternak, melainkan pengalaman beternak dan jumlah kepemilikan.

Rata-rata pekerjaan utama responden dalam penelitian ini adalah sebagai petani/peternak yaitu sebanyak 29 orang $(90,63 \%)$; dan sisanya secara berturutturut pekerjaan utama sebagai guru/pegawai/pensiunan sebanyak 2 orang $(6,25 \%)$ dan pekerjaan swasta sebanyak 1 orang $(3,12 \%)$. Hal ini dikarenakan sebagian besar penduduk di seluruh Kecamatan Insana Barat bermata pencaharian sebagai petani dengan jumlah 29 orang atau 90,63\%. Umumnya para petani peternak di Kecamatan Insana Barat dalam usaha pemelihraan sapi yang bersifat tradisional. Pemeliharaan sapi yang mereka lakukan hanya sebagai usaha sampingan saja dari petani sehingga pengelolaan bibit, terutama aspek manajemen reproduksi belum dikelola secara baik dan benar. Menurut Sugeng (2003), sementara ini usaha beternak hanya sebagai pekerjaan sampingan, untuk tambahan penghasilan tabungan untuk keluarga terutama untuk biaya pendidikan anak sekolah dan sebagian ternak merupakan warisan dari orang tua.

Dari aspek pengalaman beternak dan jumlah kepemilikan ternak menunjukkan bahwa rata-rata pengalaman beternak responden $>6$ tahun sebanyak 23 orang $(71,88 \%)$, menyusul pengalaman 4-6 tahun sebanyak 5 orang (15,63\%). Hendrayani dan Febrina (2009), yang menyatakan bahwa pengalaman bertani/beternak merupakan modal penting untuk berhasilnya suatu kegiatan usaha tani. Berbedanya tingkat pengalaman masing-masing petani maka akan berbeda pula pola pikir mereka dalam menerapkan inovasi pada kegiatan usahanya.

\begin{tabular}{|c|c|c|c|}
\hline No & Uraian & Jumlah (orang) & Persentase (\%) \\
\hline \multirow[t]{15}{*}{1} & Identitas Peternak: & & \\
\hline & a. Umur & & \\
\hline & $<45$ tahun & 7 & 21,88 \\
\hline & 45-55 tahun & 14 & 43,75 \\
\hline & $>55$ tahun & 11 & 34,38 \\
\hline & Pendidikan & & \\
\hline & Tidak Tamat SD & 3 & 9,38 \\
\hline & Tamat SD & 12 & 37,50 \\
\hline & Tamat SLTP/Sederajat & 6 & 18,75 \\
\hline & Tamat SLTA/Sederajat & 9 & 28,13 \\
\hline & Strata-1 atau Strata-2 & 2 & 6,25 \\
\hline & Pekerjaan & & \\
\hline & Petani & 29 & 90,63 \\
\hline & Guru/Pegawai/Pensiunan & 2 & 6,25 \\
\hline & Swasta & 1 & 3,12 \\
\hline \multirow[t]{4}{*}{2} & Pengalaman Beternak & & \\
\hline & 1-3 tahun & 4 & 12,50 \\
\hline & 4-6 tahun & 5 & 15,63 \\
\hline & $>6$ tahun & 23 & 71,88 \\
\hline \multirow[t]{4}{*}{3} & Jumlah Kepemilikan & & \\
\hline & $1-3$ ekor & 15 & 46,88 \\
\hline & 4-6 ekor & 11 & 34,38 \\
\hline & $>6$ ekor & 6 & 18,75 \\
\hline \multirow[t]{3}{*}{4} & Status Kepemilikan & & \\
\hline & Milik Sendiri & 31 & 96,88 \\
\hline & Garapan & 1 & 3,12 \\
\hline \multirow[t]{3}{*}{5} & Sistem Pemeliharaan & & \\
\hline & Intensif & 1 & 3,12 \\
\hline & Semi Intensif & 31 & 96,88 \\
\hline
\end{tabular}

Rata-rata jumlah kepemilikan ternak terbanyak di Kecamatan Insana Barat adalah 1-3 ekor sebanyak 15 orang (46,88\%), kepemilikkan ternak 4-6 ekor sebanyak 11 orang $(34,38 \%)$ dan hanya 6 orang $(17,75 \%)$ yang memilik ternak lebih dari 6 ekor. Sistem pemeliharaan ternak oleh peternak mayoritas menerapkan sistem semi intensif yaitu sebanyak 31 orang $(96,88 \%)$ dan hanya 1 orang $(3,12 \%)$ yang memelihara ternak dengan sistem intensif. Hasil penelitian ini bertolak belakang dengan penelitian Makatita (2013), yang menyatakan pendidikan merupakan salah satu faktor yang menunjang keberhasilan usaha skala kecil, dengan asumsi semakin tinggi tingkat pendidikan, semakin baik pengetahuannya dalam mengelola usaha.

\subsection{Kondisi Obyektif Pengelolaan Reproduksi}

Efisiensi reproduksi adalah ukuran kemampuan seekor sapi untuk bunting dan menghasilkan keturunan yang layak (Niazi dan Aleem, 2003). Data kondisi obyektif hasil pengamatan di lapangan tentang efisiensi reproduksi sapi Bali yang dikawinkan dengan bangsa sapi Brangus secara IB di wilayah Kecamatan Insana Barat dapat dijelaskan sebagai berikut:

\begin{tabular}{cc} 
Tabel 2. Efisiensi reproduksi induk Sapi Bali di Kecamatan Insana Barat \\
\hline Variabel Pengukuran & Hasil \\
\hline C R & $68,70 \pm 26,43 \%$ \\
S/C & $1,73 \pm 0,79$ \\
Lama Bunting & $272,23 \pm 3,96$ \\
CI & $384,62 \pm 48,41$ \\
\hline
\end{tabular}

Sumber: Data primer diolah (2019).

\subsection{Conception Rate}

Conception Rate (CR) adalah angka yang menunjukkan persentasi ternak yang bunting dari hasil IB pada seluruh ternak yang di inseminasi. Rata-rata angka kebuntingan atau Conception Rate induk sapi Bali yang dikawinkan dengan bangsa sapi Brangus secara IB di Kecamatan Insana Barat dari 42 ekor ternak akseptor adalah sebesar $68,96 \pm 26,43 \%$ dengan sebaran nilai $\mathrm{CR}$ bervariasi mulai dari nilai CR kurang 50\% sebanyak 9 ekor (21,43\%); kurang baik karena berada di bawah standar nasional, nilai CR antara 50-75\% sebanyak 10 ekor $(23,81 \%)$; (baik) dan nilai CR lebih dari $75 \%$ sebanyak 23 ekor $(54,76 \%)$, (sangat baik) dengan rata-rata angka kebuntingan atau Conception Rate sebesar $68,96 \%$ merupakan capaian yang bagus. Widodo (2000), menjelaskan bahwa untuk kondisi normal di Indonesia angka CR 60$75 \%$ merupakan angka CR standar Nasional. Tingginya nilai CR ini diduga disebabkan karena:1) peternak dapat mendeteksi saat birahi secara benar dan melapokan kondisi birahi sapinya kepada inseminator dengan cepat; 2) petugas inseminator yang responsif dan terampil; 3) tingginya tingkat fertelitas semen yang digunakan; dan 4) kondisi fisiologis ternak sapi betina yang sehat. Hal ini sesuai dengan Rasad et al., (2008) bahwa induk sapi yang pada saat tepat (birahi) akan memudahkan pelaksanaan IB, serta akan memberikan respon 
perkawinan yang positif, sehingga hanya dengan satu kali perkawinan, akan menghasilkan kebuntingan hal ini berpengaruh terhadap CR. Fanani et al. (2013), menyatakan bahwa nilai CR ditentukan oleh kesuburan pejantan, kesuburan betina, dan teknik inseminasi. Kesuburan pejantan salah satunya merupakan tanggung jawab Balai Inseminasi Buatan (BIB) yang memproduks semen beku disamping manajemen penyimpanan di tingkat inseminator. Kesuburan betina merupakan tanggung jawab peternak dibantu oleh dokter hewan yang bertugas memonitoring kesehatan sapi induk. Sementara itu, pelaksanaan IB merupakan tanggung jawab inseminator. Apriem et al. (2012), menjelaskan bahwa tinggi rendahnya $\mathrm{CR}$ dipengaruhi oleh kondisi ternak, deteksi birahi, deteksi estrus dan pengelolaan reproduksi yang akan berpengaruh pada fertilitas ternak dan nilai konsep.

\subsection{Service/Conception}

Service per conception (S/C) merupakan jumlah layanan IB untuk menghasilkan suatu kebuntingan pada ternak. Rata-rata nilai $\mathrm{S} / \mathrm{C}$ induk betina sapi bali yang dikawinkan dengan penjantan brangus di wilayah Kecamatan Insana Barat adalah 1,73 $\pm 0,79$, yang berarti berada dalam rentang kategori baik karena berada pada kisaran normal yaitu antara 1,6-2,0 (Toelihere, 1993). Rasio nilai S/C yang cukup tinggi menunjukkan kesuburan yang relatif baik pada induk ternak sehingga mengakibatkan berhasilnnya IB. Nilai S/C 1,73 pada penelitian ini mengindikasikan bahwa induk betina sapi bali yang dikawinkan memiliki kesuburan yang relatif tinggi $(78,57 \%)$ induk betina menjadi bunting hanya dengan1-2 kali IB. Selain itu diduga semen dari pejantan yang digunakan turut memberi kontribusi terhadap tingkat konsepsi dan nilai S/C yang tinggi dimana menurut Setiono et al. (2015), bahwa rata-rata karakteristik semen sapi bangsa brangus adalah: konsistensi kental; memiliki gerakan massa ++; motalitas individu 70\% dengan konsentrasi 1613 (jt/ml). Mantongi et al. (2013), melaporkan hasil penelitian pada bangsa sapi potong induk sapi Bali di Kecamatan Telaga Biru yang diamati memiliki nilai S/C sebesar 1,22. Tingginya rasio nilai $\mathrm{S} / \mathrm{C}$ dipengaruhi oleh terlambatnya peternak dalam mendeteksi saat birahi atau melaporkan birahi sapinya kepada inseminator, adanya kelainan pada organ reproduksi induk sapi, kurang terampil inseminator, fasilitas pelayanan inseminasi yang terbatas, dan kurang lancarnya transportasi (Hadi dan Ilham, 2000).

\subsection{Lama Kebuntingan}

Lama kebuntingan ternak sapi dipengaruhi oleh jenis sapi, jenis kelamin dan jumlah anak yang dikandung serta faktor lain seperti umur induk, musim dan letak geografis (Jainudeen dan Hafez, 2000). Rata-rata lama kebuntingan induk betina sapi bali yang dikawinkan dengan penjantan brangus di wilayah Kecamatan Insana Barat adalah 272,23 $\pm 3,96$ hari, dengan perincian yang lebih dari $(>270)$ hari sebanyak 10 ekor atau $76,92 \%$ dan sisanya memiliki lama kebuntingan kurang dari $(<270)$ hari sebanyak 3 ekor $(23,08 \%)$ yang berarti berada dalam rentang kategori baik karena berada pada kisaran normal.

Hasil Penelitian dan pengamatan yang dilakukan di Kecamatan Sungai Bahar dijumpai lama bunting sapi bali $282,24 \pm 6.50$ hari. Menurut laporan Darmadja dan Sutedja (1976), sapi bali yang dikembangkan di Bali memiliki lama bunting $286 \pm 15$ hari. Jika merujuk pada standar normal lama kebuntingan sapi Bali dari kedua peneliti ini, maka hasil penelitian ini lebih cepat dari waktu normal. Hal ini diduga karena dipengaruhi oleh jenis sapi, jenis kelamin, besar anak yang dikandung serta faktor lain seperti umur induk, musim dan letak geografis. Sedangkan menurut Astuti (1999), faktor genetik ternak menentukan kemampuan yang dimiliki seekor ternak, sedangkan faktor lingkungan memberikan kesempatan pada ternak untuk menampilkan kemampuannya. Keadaan ini mencerminkan bahwa sapi bali memiliki kemampuan adaptasi terhadap lingkungan cukup baik, akibatnya tampilan reproduksinya tidak berbeda dari daerah asalnya.

\subsection{Calving Interval}

Jarak beranak/calving interval (CI) adalah kurun waktu antara dua kelahiran yang berurutan pada seekor sapi induk. Sebaran nilai data rataan Calving interval secara berurutan dari yang jumlah terbanyak adalah $\leq 365$ hari sebanyak 8 ekor (61,54\%); antara 370-480 hari sebanyak 3 ekor $(23,08 \%)$ dan $\geq 540$ hari sebanyak 2 ekor $(15,38 \%)$ dengan rata-rata calving interval secara keseluruhan adalah $384,62 \pm 48,41$ hari atau 12,8 bulan.

Menurut Sudono et al. (2003), rentang calving interval yang ideal pada sapi Bali adalah 12-13 bulan. Selang beranak kurang dari 13 bulan, maka peternak akan mendapatkan keuntungan yang optimal. Lambatnya dilakukan perkawinan setelah beranak dan atau terjadinya kawin berulang berarti harus menunggu siklus birahi selanjutnya untuk dapat melakukan perkawinan dan hal ini akan menyebabkan tingkat konsepsi yang rendah dan berakibat pada $\mathrm{CI}$ yang panjang. Penyebab terjadinya CI yang panjang disebabkan karena para petani peternak kurang memperhatikan dan kurang memahami sikus birahi pada induk sapi dan terlambat menyampaikan kepada petugas inseminasi. Menurut Anderson et al. (2002), salah satu cara untuk meningkatkan efisiensi reproduksi ternak adalah mempersingkat jarak beranak atau calving interval yang pendek. Artinya sapi harus kembali dikawinkan lagi setelah 80-85 hari pasca beranak untuk mendapatkan jarak beranak yang baik. Secara normal induk membutuhkan waktu 36-42 hari pasca melahirkan untuk mengembalikan fungsi kinerja organ reproduksi seperti sediakala atau involusi utery (Yulyanto et al., 2014).

\subsection{Analisis Tingkat Efisiensi Reproduksi}

Analisis regresi berganda digunakan untuk mengetahui tingkat efisiensi reproduksi induk sapi bali yang dikawinkan dengan pejantan brangus dengan IB di Kecamatan Insana Barat. Analisis ini merupakan suatu analisis yang dapat mengukur seberapa besar hubungan antara jumlah akseptor IB dengan tingkat efisiensi reproduksi (Conception Rate $\left(\mathrm{X}_{1}\right)$, Service per Conception $\left(\mathrm{X}_{2}\right)$ dan Calving interval $\left(\mathrm{X}_{3}\right)$. Adapun hasil analisis regresi dapat dilihat pada Tabel 3.

\begin{tabular}{|c|c|c|c|c|}
\hline Model & $\mathrm{R}$ & R Square & Adjusted R Square & $\begin{array}{l}\text { Std. Error of the } \\
\text { Estimate }\end{array}$ \\
\hline 1 & $.702^{\mathrm{a}}$ & .493 & .439 & .353 \\
\hline
\end{tabular}

Service/Conception $(S / C)$; b. Dependent Variable: Akseptor IB

Berdasarkan hasil analisis regresi linier berganda diperoleh nilai koefisien regresi (r) sebesar 0,702. Hal ini menunjukkan terdapat hubungan yang positif dan erat antara jumlah akseptor IB, dengan tingkat efisiensi reproduksi induk sapi bali yang dikawinkan dengan pejantan brangus dengan IB. Koefisien determinasi $\left(\mathrm{R}^{2}\right)$ sebesar 0,493 memberi pengertian bahwa besarnya tingkat jumlah akseptor IB dapat diterangkan oleh Conception Rate, Service per Conception dan Calving Interval sebesar 49,3\%, dan selebihnya $50,7 \%$ efisiensi reproduksi ternak sapi bali hasil IB berhubungan dengan faktor lain yang tidak diteliti, misalnya faktor kesehatan ternak, kebijakan pemerintah dan sistem pemeliharaan makro lainnya.

Hasil analisis variansi untuk mengetahui tingkat keeratan hubungan yang mempengaruhi jumlah akseptor IB dengan tingkat efisiensi reproduksi induk sapi bali yang dikawinkan dengan pejantan brangus dengan IB di Kecamatan Insana Barat seperti tersaji pada Tabel 4.

Tabel 4. Koefisien Determinasi dan Uji F

\begin{tabular}{llccccc}
\hline & Model & $\begin{array}{c}\text { Sum of } \\
\text { Squares }\end{array}$ & Df & $\begin{array}{c}\text { Mean } \\
\text { Square }\end{array}$ & F & Sig. \\
\hline \multirow{2}{*}{1} & Regression & 3.389 & 3 & 1.130 & 9.075 & $.000^{\mathrm{b}}$ \\
& Residual & 3.486 & 28 & .124 & & \\
& Total & 6.875 & 31 & & & \\
\hline
\end{tabular}
Interval (CI), Conception Rate (CR), Service/Conception ( $/ C$ )

PadaTabel 4 terlihat bahwa nilai $\mathrm{F}$ hitung $(9.075)>\mathrm{F}$ tabel $(2,947)$ memberikan pengertian bahwa model persamaan $Y=a+b_{1} X_{1}+b_{2} X_{2}+b_{3} X_{3}$ dapat diterima. Dimana faktor $\mathrm{CR}, \mathrm{S} / \mathrm{C}$ dan CI memiliki hubungan yang sangat nyata $(\mathrm{P}<0,01)$ dengan jumlah akseptor sapi bali hasil IB. Untuk mengetahui persamaan garis regresi berganda dan nilai t dari setiap variabel dapat dilihat pada Tabel 5 .

Tabel 5. Nilai Koefisien Regresi dan Uji T

\begin{tabular}{|c|c|c|c|c|c|}
\hline \multirow{2}{*}{ Model } & \multicolumn{2}{|c|}{$\begin{array}{l}\text { Unstandardized } \\
\text { Coefficients }\end{array}$} & \multirow{2}{*}{$\begin{array}{c}\begin{array}{r}\text { Standardized } \\
\text { Coefficients }\end{array} \\
\text { Beta }\end{array}$} & \multirow[t]{2}{*}{$\mathrm{T}$} & \multirow[t]{2}{*}{ Sig. } \\
\hline & B & Std. Error & & & \\
\hline (Constant) & 6.256 & 1.019 & & 6.142 & .000 \\
\hline $\mathrm{S} / \mathrm{C}$ & $1 . \overline{340}$ & .286 & -2.039 & 4.680 & .000 \\
\hline $\mathrm{CR}$ & -.039 & .008 & -2.198 & -5.050 & .000 \\
\hline $\mathrm{CI}$ & .000 & .000 & .102 & .752 & .459 \\
\hline
\end{tabular}

Dependent Variable: Akseptor IB

Berdasarkan hasil perhitungan pada Tabel 5 dapat dibuat persamaan regresi berganda untuk hubungan antara jumlah akseptor IB dengan tingka efisiensi reproduksi induk sapi bali yang dikawinkan dengan pejantan brangus dengan IB adalah: $\mathrm{Y}=6.256-1.340 \mathrm{X}_{1}-0.039 \mathrm{X}_{2}+0.000 \mathrm{X}_{3}$. Hasil analisis regresi menunjukkan bahwa variabel $\mathrm{S} / \mathrm{C}$ menunjukkan hubungan yang negatif dan signifikan antara jumlah akseptor IB dengan tingkat efisiensi reproduksi induk sapi bali yang dikawinkan dengan pejantan brangus dengan IB di Kecamatan Insana Barat dengan nilai regresi sebesar -1.340 , dan nilai t sebesar -4.680 serta tingkat signifikan $0,000<0,05$ (signifikan). Hal ini mengindikasikan bahwa nilai $\mathrm{S} / \mathrm{C}$ di Kecamatan Insana Barat berada pada tingkat yang baik yakni 1,70 (berada dalam kisaran normal) yaitu antara 1,6-2,0. Nilai S/C in memberikan dampak yang positif bagi peternak dan inseminator. Sulaksono et al. (2010) menyatakan bahwa tinggi rendahnya nilai $\mathrm{S} / \mathrm{C}$ dapat dipengaruhi oleh beberapa faktor antara lain keterampilan inseminator, waktu dalam melakukan IB dan pengetahuan peternak dalam mendeteksi birahi. Angka S/C jika berada pada angka di bawah 2 yang berarti sapi masih dapat beternak 1 tahun sekali, apabila angka $\mathrm{S} / \mathrm{C}$ di atas 2 akan menyebabkan tidak tercapainya jarak beranak yang ideal dan menunjukkan reproduksi sapi tersebut kurang efisien yang membuat jarak beranak menjadi lama, sehingga dapat merugikan peternak karena harus mengeluarkan biaya IB lagi.

CR pada penelitian ini merupakan variabel $\left(\mathrm{X}_{2}\right)$ terhadap jumlah akseptor IB (Y) yang menghasilkan nilai regresi sebesar $-0,039$ dan nilai $t$ sebesar -5.050 dengan tingkat signifikan 0,000<0,05 (signifikan). Rata-rata CR dari hasil penelitian ini adalah sebesar 68,96\%. Fanani et al. (2013), menyatakan bahwa nilai CR yang baik mencapai 60-70\%. Hasil ini mengindikasikan bahwa CR di Kecamatan Insana Barat berada pada tingkat 
yang baik namun mendekati nilai ambang batas normal yang diisyaratkan untuk itu dan masih harus terus ditingkatkan lagi. Hasil penelitian Nuryadi dan Wahjuningsih (2011), di Kabupaten Malang bahwa nilai CR sapi peranakan limousin sebesar 66\%. Angka CR pada kelompok ternak hasil penelitian juga dipengaruhi oleh besarnya rata-rata nilai $\mathrm{S} / \mathrm{C}$

CI atau jarak beranak adalah jumlah hari atau bulan akumulasi antara kelahiran satu dengan kelahiran berikutnya. Pada penelitian ini menunjukkan bahwa Calving Interval (X3) menghasilkan nilai regresi sebesar 0.000 dengan nilai t sebesar 0,752 dan angka tingkat signifikan adalah 0,459>0,05 (tidak signifikan), yang berarti tidak memiliki pengaruh yang nyata pada jumlah akseptor IB. Hal ini mengindikasikan bahwa CI di Kecamatan Insana Barat berada pada tingkat yang kurang baik, dimana hasil penelitian ini adalah sebesar 384,62. Menurut data dilapangan tingginya persentase Calving Interval disebabkan oleh beberapa hal mulai dari manajemen pemeliharaan yang kurang bagus karena walau ternak telah di kandangkan tetapi pola pemberian pakan ternak masih merenggut sendiri dilapangan (diikat dengan tali) masih tergolong dalam pola pemeliharaan secara tradisional.

\section{Simpulan}

Dari serangkaian uraiaan pembahasan di atas dapat disimpulkan bahwa rata-rata induk sapi bali yang dikawinkan secara IB dengan semen pejantan sapi brangus memberikan efisiensi reproduksi yang baik dan di atas normal dengan nilai masing-masing variabel adalah: $\mathrm{CR}: 68,70 \pm 26,83 \%$; $\mathrm{S} / \mathrm{C}: 1,73 \pm 0,79$; Lama kebuntingan: $272,23 \pm 3,96$ hari, CI: 384,62 \pm 48,41 hari. Efisiensi reproduksi induk sapi bali yang dikawinkan secara IB dengan semen pejantan sapi brangus memiliki keeratan hubungan dengan Service Per Conception, Conception Rate dan Calving interval.

\section{Pustaka}

Anderson, L. H., W. R. Burris, J. T. Johns, and K. D. Bullock. 2002. Managing body condition to improve reproductive efficiency in beef cows. University of Kentucky College of Agriculture.

Apriem, F., N. Ihsan, dan S. B. Poetro. 2012. Penampilan Reproduksi Sapi Peranakan Ongol Berdasarkan Paritas di Kota Probolinggo Jawa Timur. Tesis. Fakultas Peternakan, Universitas Brawijaya, Malang.

Astuti. M.J. 1999. pemuliaan Ternak, Pengembangan dan Usaha Perbaikan Genetik Ternak Lokal. Pidato Pengukuran Guru Besar Dalam Ilmu Pemuliaan Ternak Pada Fakultas Peternakan Universitas Gadjah Mada, Yogyakarta.

BPS Kabupaten Timor Tengah Utara. 2018. TTU Dalam Angka. Badan Pusat Statistik Kab. TTU. Kefamenanu.

BPS Provinsi Nusa Tenggara Timur. 2019. NTT Dalam Angka. Badan Pusat Statistik Prov. NTT. Kupang.

Darmadja, D. dann P. Sutedja. 1976. Masa Kebuntingan dan Interval Beranak Pada Sapi Bali. Prosiidiing Seminar Reproduksi Sapi Bali. Dinas Peterrnakan I Bali. Denpasar.

Dirjen Peternakan dan Keswan. 2018. Populasi Sap Potong di Nusa Tenggara Timur Pada Tahun 2016-2017.

Fanani, S., Y. B. P. Subagyo, dan Lutojo. 2013. Kinerja Reproduksi Sapi Peranakan Friesian Holstein (PFH) di Kecamatan Pudak, Kabupaten Ponogoro. J. Tropical Animal Husbandry, 2: 21-27.

Feradis. 2010. Bioteknologi Reproduksi Pada Ternak. Alfabeta. Bandung.

Hafez, E.S.E 1993. Artificial Insemination. In : HAFEZ, E.S.E. 1993. Reproduction in farm Animal.

Hariadi, M., S. Hardjopranjoto, Wurlina, H.A. Hermadi, B. Utomo, Rimayanti.,I.N. Triana dan H. Ratnani. 2011. Ilmu Kemajiran pada Ternak. Cetakan 1. Airlangga University Press. Surabaya.

Hadi, P. U. dan Ilham, N. 2000. Problem dan Prospek Pengembangan Usaha Pembibitan Sapi Potong. Jurnal Litbang Pertanian, 21 (4) : 148-157.

Hendrayani, M dan D. Febrina 2009. Analisis faktor-faktor yang mempengaruhi motifasi beternak sapi di desa Koto Benai Kecamatan Benai Kecamatan Benai Kabupaten Kuantan Sengingi. Jurnal Peternakan, $6(2): 53-62$.

Jaeinudeen, M.R. dan Hafez, E.S.E. 2000. Cattle and Buffalo. Dalam Hafez, B. Dan Hafez E.S.E. Reproduktion in Farm Animals. Lippincott Williams and Wilkins, Philadelphia. Halaman : 159-171.

Kurniawan, E. 2012. Analisis Potensi Pengembangan Peternakan Sapi Potong di Kecamatan Bungkal Kabupaten Ponorogo. Skripsi. Surakarta: Universitas Sebelas Maret.

Makatita, J. 2013. Hubungan Antara Karakteristik Peternak Dengan Skala Usaha Pada Usaha Peternakan Sapi Di Kecamatan Leihitu Kabupaten Maluku Tengah. Jurnal Agrinimal, 3(2) : 78-83.

Mantongi R. I., S. Fathan dan F. Ilham. 2013. Evaluasi Tingkat Keberhasilan Inseminasi Buatan Pada Sapi Potong di Kecamatan Telaga Biru Kabupaten Gorontalo.Laporan Penelitian. Program Studi Peternakan, Jurusan Peternakan, Universitas Negeri Gorontalo.

Niazi, A. A. K and M. Aleem. 2003. Comparative Studies on the Reproduktive Efficiency of Importet and Lokal Born Friesian Cows in Pakistan. Journal of Biological Sciences, 3 (4) : 388-395.

Nuryadi dan Wahjuningsih, S. 2011. Penampilan Reproduksi Sapi Peranakan Ongole dan Peranakan Limosin Di Kabupaten Malang. J. Ternak Troopika, 12 (1): $76-81$.
Rasad, S.D., Kuswaryan, S., Sartika, D., Salim,, R. 2008. Kajian Pelaksanaan Inseminasi Buatan Pada Sapi Potong di Jawa Barat. Prosiding Seminar Nasional Sapi Potong Palu, 24 November 2008: 104-114.

Sariubang, M., Andi, E., Pasambe, D. Dan Bahar, S. 2001. Pengaruh Bangsa Sapi Pejantan Terhadap Produktivitas Pedet Sapi Potong Hasil Inseminasi Buatan, http://peternakan.litbang.pertanian.go.id. Diakses 10 Mei 2019.

Setiono, N., Suharyati, S. dan Santoso, P. E. 2015. Kualitas Semen Beku Sapi Brahman Dengan Dosis Krioprotektan Gliserol Yang Berbeda Dengan Dalam Bahan Pengencer Tris Sitrat Kuning Telur. Jurnal Ilmiah Peternakan Terpadu, I (3). 61-69.

Sarwono, J. 2006. Analisis Data Penelitian. Penerbit Andi. Yogyakarta.

Sugeng, Y. B. 2003. Pembibitan Ternak Sapi. Gramedia. Jakarta.

Sugiyono. 2010. Metode Penelitian Pendekatan Kuantitatif,Kualitatif, dan R\&d. Alfabeta: Bandung.

Toelihere, M.R. 1993. Inseminasi Buatan pada ternak. Angkasa Bandung. G.W.Salisbury-N.I.Vandermark Diterjemahkan oleh. Prof. Drh. R. Djanuar. 1995. Fisiolgi Reproduksi dan Inseminasi Buatan pada ternak.

Sulaksono, A., Suharyati, S., dan Santoso, E. P. 2010. Penampilan Reproduksi (service per conception, Lama Bunting dan Selang Beranak) Kambing Boerawa Di Kecamatan Gedong Tataan dan Kecamatan Gisting. Fakultas Pertanian Universitas Lampung. Lampung.

Sudono, A., F. Rosdiana dan S, Budi 2003. Beternak Sapi Perah. PT. Agromedia Pustaka, Jakarta.

Widodo, P. 2000. Pengkajian Pelaksanaan Program Inseminasi Buatan Pada Sapi Potong di Kabupaten Daerah Tingkat II Blora, Jawa Tengah. Skripsi. Institut Pertanian Bogor, Bogor.

Waris, N., Badriyah, D. dan Wahyuning, A. 2015. Pengaruh Tingkat Pendidikan dan Lama Beternak Terhadap Pengetahuan Manajemen Reproduksi Ternak Sapi Potong di desa Kedungpring Kecamatan Balongpanggang Kabupaten Gresik. Program Studi Peternakan. Universitas Islam Lamongan. Jurnal ternak, 06 (01): 30-33.

Yulyanto, C. A., T. Susilawati dan M. Nur Ihsan. 2014. Penampilan Reproduksi Sapi Perananakan Ongole (PO) dan sapi Peranakan Limousin di Kecamatan Sawoo Kabupaten Ponorogo dan Kecamatan Tugu Kabupaten Trenggalek. J. Ilmu-ilmu Peternakan, 24 (2): 4. 